\title{
Microscopic Evaluation of Protective Coating by Coated Sheets after Corrosion Load
}

Sylvia Kuśmierczak, Jaroslava Svobodová

Faculty of Technology and Production Management, University of J. E. Purkyně in Ústí nad Labem, Pasteurova 3334/7, 40001 Ústí nad Labem, Czech Republic. E-mail: kusmierczak@fvtm.ujep.cz

Introduction into problems - The aim of the paper was microscopically analyze protective layer by coated sheets after corrosion loading which were pre-treated by various ways. The samples were divided into 4 groups according to the pretreatment type and duration of corrosion load. After a corrosive effect on the corrosion chamber the protective layer was subjected to microscopic evaluation. For samples of group I and IV have to degrade the protective layer and the formation of corrosion products on the base material which causes degradation of the protective layer and shorten its life. For samples of group II and III microstructural analysis showed good condition of the painted surface layer and the base material showed no presence of corrosion products. It again confirms the need for compliance of technological conditions for the pretreatment of the surface particularly in the application of modern less aggressive means.

Keywords: corrosion, surface pretreatment, surface protection, corrosion products, painted surface layer

\section{Acknowledgement}

This paper was created with the support of the Internal student grant FVTM UJEP č. 4820215000401.

\section{References}

[1] BORKOWSKI, S., STASIAK-BETLEJEWSKA, R., (2010). Analysis of anti-corrosion coating process on steel constructions, Manufacturing technology, vol. X., p. 27-29, ISSN 1213-2489.

[2] LEIDHEISER JR., HENRY, CORROSION OF PAINTED METALS - A REVIEW, Corrosion,Volume 38, Issue 7, July 1982, p. 374-383, ISSN 00109312.

[3] EMIRA, H.S., SHAKOUR, A .A., REHIM, S.S.A.E., Evaluation of corrosion protection of carbon steel by anticorrosive paints, Anti-Corrosion Methods and Materials Volume 59, Issue 5, September 2012, p. 255-262, ISSN 00035599.

[4] GUENBOUR, A., BENBACHIR, A., KACEMI, A., Evaluation of the corrosion performance of zinc-phosphate-painted carbon steel, Surface and Coatings Technology, Volume 113, Issue 1-2, 12 March 1999, Pages 36-43, ISSN 02578972.

[5] KREISLOVA, K., KNOTKOVA, D., KOPECKY, L. Changes in corrosion rates in atmospheres with changing corrosivity, Corrosion Engineering Science and Technology Volume 44, Issue 6, December 2009, Pages 433-440, ISSN 1478422.

[6] JANKURA, D., DRAGANOVSKÁ, D., BREZINOVÁ, J. The analysis on the structure and adhesive properties of ceramics and composite coatings, Chemicke Listy Volume 105, Issue 16 SPEC. ISSUE, 2011, Pages 542-545, ISSN 00092770.

[7] ITOH, Y., SHIMIZU, Y., KITANE, Y. Corrosion resistance of painted steel plate edges prepared with different corner geometries examined by combined cyclic corrosion test, Doboku Gakkai Ronbunshuu A Volume 66, Issue 1, 2010, Pages 68-78, ISSN 18806023.

[8] HAUSBRAND, R., STRATMANN, M., ROHWERDER, M. Corrosion Science, Corrosion of zinc-magnesium coatings, Mechanism of paint delamination, Volume 51, Issue 9, September 2009, Pages 2107-2114, ISSN 0010938X.

[9] [cit. 17.9. 2012], available at www: http://www.povrchovauprava.cz/uploads/assets/casopisy/pu-2009-01.pdf

[10] [cit. 17.9. 2012], available at www: http://www.povrchoveupravy.cz/2005-04-clanek01.html.

[11] [cit. 17.9. 2012], available at www: http://www.tiger-coatings.com/.

[12] [cit. 17.9. 2012], available at www: http://www.salum.cz/cz_press_povrchova_uprava.htm.

[13] KALINCOVA, D., BARBORAK, O., ANDREJCAK, I. (2011). Quality of chrome layers of coining dies and its impact on their reliability and lifetime in operation. In: Kovove materialy. Vol. 49, no. 6, pp 457-461. 